\title{
Transfer investment on education on a free cost basis: some evidence from Portugal, Spain, Greece and Italy
}

\author{
Luisa Cerdeira a \\ Belmiro Cabrito ${ }^{a}$ \\ Maria Lourdes Machado-Taylor b \\ Tomás Patrocínio ${ }^{a}$
}

\section{Abstract}

For decades, education has been viewed as an instrument for social mobility and also as a tool for economic growth and social development. Over the recent years, we have witnessed an output movement of highly qualified graduates, from peripheral southern Europe to the more developed countries of the EU and OECD. In this article, we analyse the reality of four countries: Portugal, Spain, Greece and Italy. In order to examine the socio-economic impact of this brain drain, it will be introduced an estimation using OECD statistics (2014) of the public and private costs to educate a student from primary schooling through a higher education degree. In spite of the differences among these countries' experiences, there is no doubt that these countries "offered" high qualified workers for free or at a zero cost basis to the "importing" countries.

Keywords: Private and public costs of education. Higher education. Highly skilled emigration.

\section{Introdução}

The so-called "brain drain" phenomenon refers to "the international transfer of human resources and mainly applies to the migration of relatively highly educated individuals from developing to developed countries" (BEINE; DOCQUIER; RAPOPORT, 2008, p. 631). So, the expression "brain drain" refers to the transfer of human capital with levels of higher education and skills from the least developed countries to the most developed ones (CASTLES; MILLER,

\footnotetext{
a University of Lisboa, Institute of Education. Lisbon, Portugal.

${ }^{b}$ Centre for Research in Higher Education Policies - CIPES. Matosinhos, Portugal.

Recebido em: 22 mai. 2016

Aceito em: 08 jul. 2016
} 
2003; HAMILTON, 2003). The use of this expression should, therefore, apply strictly to those movements identified as "high-skilled South-to-North migration" (LODIGIANI; MARCHIORI; SHEN, 2013), as it convenes the effects that human capital transferences can have over the economy and welfare of sending societies, namely: its reflexes on their educational systems, their propensity for new technologies' use, the income of emigrants' remittances; in sum, what could be identified as an economical brain gain (or waste) for the sending country.

This unequal emigration accentuates the asymmetric distribution of resources in the process of educational, cultural and economic globalization (HEUER, 2011). This situation makes it urgent to study and to counteract the negative effects arising from this kind of emigration, which leads less developed economies to an enhanced skill gap in research, production and public and private services. On the other hand, more developed countries will use this highly qualified human capital on a free cost basis, since their training has taken place and has been financed abroad.

Although, in general, when researchers refer to the South, they mean the Southern countries from Latin America, Africa or some from Asia, within the scope of developed countries, that "title" may embrace South European countries, such as Portugal, Spain, Italy or Greece, vis à vis the more developed countries of Northern Europe. In fact, the highly qualified migration from these countries to the more developed ones may be so strong that it is imperative to study its numbers. Among these four countries, Portugal seems to be the one where this phenomenon is more visible. In fact, Portugal would be one of the European countries where the brain drain has been more accentuated over the last decade, where the proportion of workers with a higher education degree who have emigrated in recent years is estimated at 19.5\% (DOCQUIER; MARFOUK, 2007).

\section{The Bologna Declaration and higher education in the European Higher Education Area}

\subsection{The Bologna Declaration and the comparability of higher education systems}

For the understanding of the reality under analysis in this article - the issue of highly skilled emigration - it should be understood, first and foremost, how these emigrants graduate, which brings us back to the explanation of the higher education system of the countries under study. 
Despite the specificities of each educational system, it should be noted that the four countries, all belonging to the European Union and signatories of the Bologna Declaration, witnessed, from 2006 onwards, the reorganisation of higher education so as to make it more "comparable" with the remaining signatory countries, both in terms of the processes and the results of this educational level.

In fact, the development of the European Union and of its Member-States is based on a set of principles such as freedom of movement of capital, goods and individuals. With regard to the mobility of individuals, one of the problems was the difficulty in recognizing qualifications and competences that each individual held, given the existence of several educational systems, as many as the Member-States, which were different according to the structure of the system, name and duration of the programmes, subjects and curricular units taught, assessment modes, etc.

Until 2006, before the Bologna Declaration, the accreditation of a higher education diploma attained in a European country by another one entailed, thus, the attribution of a set of equivalences between curricular units, resulting in a casuistic, individual, time consuming and highly bureaucratic process.

The resolution of this problem grounded the creation of a European Higher Education Area (which is even more extensive than the European Union itself) and the proposals of higher education reforms in Europe, which the 25 European education ministers have agreed on and that were embodied in the Bologna Declaration, in 1999.

The acknowledgement of the necessity to overcome this difficulty, as well as of the need for the recognition of qualifications and competences, explained and justified, to a large extent, the creation of a mechanism that would make it easy and immediate to measure and compare learning, competences and experiences through a device that would recognize, in an "automatic" way, the diplomas issued by each country.

The Bologna Declaration has contributed to solving this issue by proposing the use of the European Credit Transfer System (2003). With this comparison device, each individual's knowledge and competences are measured in credits, which can be compared, certified and freely used in any signatory country of the Bologna Declaration, as they represent standard units: the ECTs.

With the European Credit Transfer System, what is compared are no longer academic degrees (which sometimes did not even have a semantic equivalent 
in some countries), but rather credits. Each credit is determined in terms of the number of hours that the student needs, on average, to complete each curricular unit of a higher education study programme; each year of higher education corresponds to 60 ECTs and represents a set of competences recognized by all subscribers of the Bologna Declaration.

With the ECT system, diplomas obtained in a signatory country of the Bologna Declaration are immediately accepted in the remaining signatory countries, depending on the number of credits that the student holds.

\subsection{The Bologna Declaration and the structure of European higher education}

The application of the principles of the Bologna Declaration was, from the outset, hindered by the fact that the higher education systems of many European countries do not have a similar structure. Degrees and diplomas are different, and so are the number of years needed do attain each of these diplomas. This required, therefore, a true revolution in educational systems that would lead to some uniformity in the higher education structure and that was materialized, among others, in the following question: what is the number of years and credits required for the student to attain a higher education diploma?

Obviously, there was not a single, but rather several answers to this question, especially if we consider the fact that, before the implementation of the Bologna Declaration, in some countries there was only university education (UK, Spain, etc.), whereas in others there was university education and polytechnic education (France, Germany, Portugal, etc.). Furthermore, in some countries the graduation was done in a single stage with a duration of four/five (or even six years in particular fields such as medicine), whereas in other countries there were short educational paths (two/three years) and long ones (four/five or even six years), etc.

Given this diversity, basically centred in the Anglo-Saxon model (which was characterized by a first cycle of three years and a first undergraduate degree; a second cycle of two years, with the master degree corresponding to these five years; and third cycle of three years, which resulted in a $\mathrm{PhD}$ ) or in the continental model (which was characterized by a first cycle of four/five years that corresponded to a first degree; a second cycle of two/three years, which corresponded to the master; and a third cycle of three or more years, which granted the $\mathrm{PhD}$ diploma), the "Bologna Europe" was forced to take an option. This option fell on the Anglo-Saxon model, the $3+2+3$ years model, although each country may apply it in its specific context. Thus, a three-year $1^{\text {st }}$ cycle and 
a two-year $2^{\text {nd }}$ cycle in one country may be replaced by a four-year $1^{\text {st }}$ cycle and a one-year $2^{\text {nd }}$ cycle in other countries, or by a single five-year integrated cycle.

However, circulation and equity require the adoption of a higher education structure that is as similar as possible (HORTALE; MORA, 2004); hence, the previous diversity came, for reasons that had to do with the recognition and circulation of intellectual capital, to the uniformity, despite recognizing the possibility of differentiated individual initiatives.

Thus, in accordance with the Bologna Declaration, European higher education is structured in three cycles and, at the end of each cycle, the student receives a diploma that grants:

- the bachelor degree, at the end of the $1^{\text {st }}$ cycle;

- the master degree, at the end of the $2^{\text {nd }}$ cycle;

- the PhD degree, at the end of the $3^{\text {rd }}$ cycle.

Notwithstanding some particular differences, the three cycles have a similar duration:

- the $1^{\text {st }}$ cycle is, in most countries of the European Union, three years long (in Spain this cycle is four years long);

- The $2^{\text {nd }}$ cycle is two years long (in Spain this cycle is one year long);

- The $3^{\text {rd }}$ cycle consists of two parts: a first year, with teaching activities and that ascribes an Advanced Training Programme diploma, whose completion with, at least, 14 points on a scale from 0 to 20 , is a necessary condition to carry on $\mathrm{PhD}$; subsequently, the $\mathrm{PhD}$ student has three more years for his/her research and writing of the thesis report, which will be discussed in a public examination.

This "homogenization" aimed to enable the comparability of graduates' academic qualifications and, thus, make it easier for individuals to move between the European Union countries.

These individual initiatives are, naturally, almost non-existent, given that diversity is expensive for countries and students, with losses in their 
competitiveness. After all, and in a perspective that is very close to human capital theories (SCHULTZ, 1961), there is no economic rationale that justifies "spending" more time to get an undergraduate diploma that, in the global market, will be worth the same as a diploma obtained in less time. International competition, particularly with the United States (US), was a factor weighing in the choice of the higher education model to adopt in the signatory countries of the Bologna Declaration. The choice of the $3+$ $2+3$ years model has established itself as the one that ensures the highest productivity gains to their intellectual capital, which makes us question the actual suitability of the current model since, somehow, the ratification of the Bologna Declaration is explained by economic reasons - the requirements of the international market - and not by reasons that are internal to the educational systems, and, thus, this process is likely to have very negative consequences in the construction of the European Union-Social Europe, both at the teaching and research levels (DUCLERT; CHARIOT, 2003). In fact, there are several social scientists advocating that, rather than discussing the validity of the adopted model, we should worry about the supremacy of the economic sphere over the educational one, resulting in the commodification of education and the European university (BARKHOLT, 2005) and in the fact that the desired link between higher education and the real world (ZAHARIA; GIBERT, 2005) will become the primary objective of this educational level, while the participation of students and families in the funding of institutions reaches increasingly commercial values (CABRITO, 2002; CERDEIRA, 2009; CERDEIRA et al., 2014), leading equity, democratization and basic research to fall behind (CHARLE et al., 2004).

Still within the scope of the construction of the European Higher Education Area, it should be stressed that the European Union has set the Europe 2020 strategy, in which a set of goals in various fields (economic, social, education, science, energy, etc.) were established, aiming to promote sustainable and inclusive development, making Europe more competitive in the global context. One of these goals was to increase, among younger population (30-34 years), the attainment of the higher education level, pointing to the European target of $40.0 \%$ for this age group.

When comparing the evolution of the countries under analysis in this article, somewhat different situations have been found, concerning both the starting point and the rate of growth towards the goals, and even the target that each country seeks to attain by 2020 (see Table 1). 
Table 1. Tertiary Education Attainment of the Population 30-34 Years (\%). ${ }^{1}$

\begin{tabular}{lcccccccccc}
\hline Variable & $\mathbf{2 0 0 0}$ & $\mathbf{2 0 1 0}$ & $\mathbf{2 0 1 1}$ & $\mathbf{2 0 1 2}$ & $\mathbf{2 0 1 3}$ & $\mathbf{2 0 1 4}$ & $\mathbf{2 0 1 5}$ & Target & $\begin{array}{c}\text { Dif } \\
\text { 2015-2000 }\end{array}$ & $\begin{array}{c}\text { Dif } \\
\text { 2015-Target }\end{array}$ \\
\hline Portugal & 11.3 & 24.0 & 26.7 & 27.8 & 30.0 & 31.3 & 31.9 & 40.0 & 20.6 & -8.1 \\
Spain & 29.2 & 42.0 & 41.9 & 41.5 & 42.3 & 42.3 & 40.9 & 44.0 & 11.7 & -3.1 \\
Greece & 25.4 & 28.6 & 29.1 & 31.2 & 34.9 & 37.2 & 40.9 & 32.0 & 15.5 & 8.9 \\
Italy & 11.6 & 19.9 & 20.4 & 21.9 & 22.5 & 23.9 & 25.3 & 26.0 & 13.7 & -0.7 \\
EU 28 & 22.4 & 33.8 & 34.8 & 36.0 & 37.1 & 37.9 & 38.7 & 40.0 & 16.3 & -1.3 \\
$(27)$ & & & & & & & & & &
\end{tabular}

EU: European Union.

Source: Eurostast (LFS). Elaborated from European Thematic Fiche. Tertiary Education Attainment (2016).

All these countries have set different goals to be attained by 2020, with Spain being the most ambitious one (44.0\%), and Italy, somewhat surprisingly, setting a very low goal (26.0\%). In 2000 Portugal and Italy were the countries that had the lowest figures, with less than half of Spain and Greece's values. Portugal was, in this group of countries, the one that saw the highest growth in the percentage of young people who have concluded higher education, rising from $11.3 \%$ to $31.9 \%$, but still far from the European Union (EU) average and the goal it has set. Italy is the country with the lowest figure in the context of the European Union and one of the countries where it is necessary to fight the dropout rate and the too long time to conclude higher education.

\subsection{Freedom of human resources movement and skilled emigration}

The construction of both the European Economic Area and the knowledge society, in which the EU sought/seeks to become, required, thus, the free movement of intellectual capital among Member-States. If the construction of a Monetary and Financial Union required a common currency and the free movement of goods and capital, the construction of a Social Europe, of a European Union would only be feasible with the free movement of "intelligence". In this sense, the Bologna Declaration was a European educational policy measure, which materialized in educational policy measures with changes in the higher education systems of all Union Member-States.

Given this situation, the freedom of movement of workers has become a reality; this movement starts, sometimes, still in situations of transitional mobility of future workers - the students. Several educational measures have competed for this, namely the Erasmus Programme, which promotes student mobility and

Note: The indicator covers the share of population aged 30-34 years having successfully completed ISCED 5 to 8. 
that materializes an educational policy measure that becomes, sometimes, the beginning of a future process of skilled emigration.

After concluding their studies, new graduates (and also those who are already in the labour market) are faced with the possibility of living transitional work experiences in other countries of the European Union or even experiences of permanent emigration. Freedom of movement of individuals makes this extension of the labour market for European citizens a reality.

However, in the current framework of development and crisis that Europe is experiencing, the search for employment in the European wider market is the result of an unprecedented job crisis that results in the unemployment of thousands of graduates, particularly in the countries with a more fragile economy and, therefore, with less responsiveness to the crisis in which they are immersed.

Thus, in some countries recent graduates are faced with a depressed market, unable to take advantage of the highly skilled labour force that the educational system produces. For these unemployed persons, the solution is, sometimes, the search for new training, so as to increase their employability. Under these circumstances, it is possible to understand the extraordinary growth that Europe has experienced in the demand for training, materialized in lifelong learning.

However, there are cases where this supply/demand for training is not sufficient to improve individuals' employability, due to the continuing economies in crisis. This has been happening in some countries, especially in the ones from southern Europe. As a consequence of these difficulties, some countries are witnessing the exit of highly skilled labour force to countries that need the skills that those workers possess. The phenomenon of highly skilled emigration is taking place and has not been matched by effective policies to attract these emigrants to return to their home countries.

\section{Exodus versus Diaspora? A theoretical hypothesis}

The research, approaching a highly qualified population, commits, necessarily, to the advantages such qualifications might represent for the individuals in their professional goals and achievements, but also to the extent, once the concept of mobility is highlighted, to which these qualifications are transferable. In this perspective, the potential of mobility of this population can be envisaged as a measure of the value of its qualifications but also of the relationship between the individual and the context. 
The major relevance of explicit knowledge seems to rely on a tray that distinguishes highly qualified emigrant individuals from lower qualified ones; since, contrary to what happens with lower qualified emigrants, the reliance that highly qualified individuals have on their skilful heritage would seem to suffice for the attainment of their goals and achievements through emigration (LIEBIG, 2004). On the other hand, and if we restrict the analysis to the European context, a set of different programs encouraging mobility in the EU space would explicitly reinforce the stimuli to students' exchange programs, but this would also be the case for some professional categories as, for instance, academics.

In general, European countries have witnessed, particularly over the last decade, a boom of participation in exchange programs of various sorts and especially concerning students looking for an inter-cultural experience, but also aiming to finish their academic studies. In 1987/1988, the Student Mobility Programme (Erasmus) started in a very shy and limited way, with the participation of only 3,244 students, but it gradually experienced a greater demand for increasing numbers of students. Although the students in mobility are still a very small minority (in 2013/2014 there were 272,497 students), in 2012/2013 there were 3 million students with a mobility experience (on average, about $5.0 \%$ of graduates in $2012 / 2013$ had had a mobility experience, as it can be observed in the next figure).

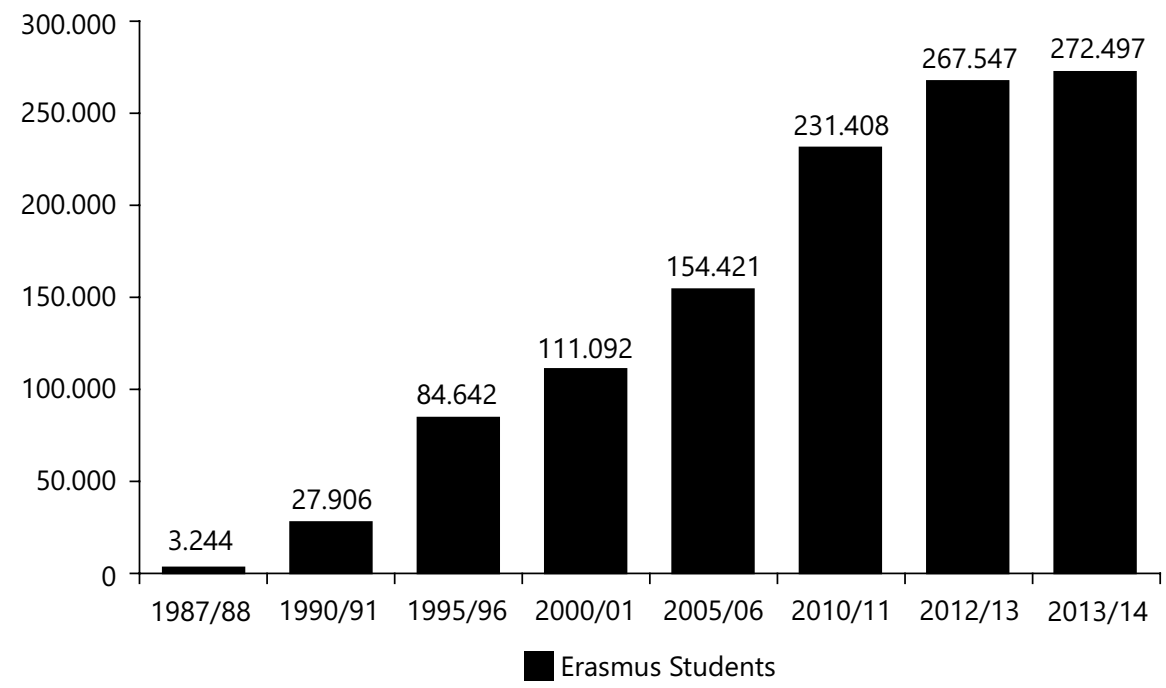

Source: Produced by the authors from: European Commission (2015). Access on: March 2016.

Figure. Growth in student mobility since the start of the Erasmus programme. 
The importance of such groups is not to be neglected; indeed, such programs seem to provide networks of a different sort that one can later profit from. If the exchanging experience is temporary and, in regular conditions, the stimuli to exchange does not concern a migrant issue - Breinbauer (2007) refers the example of the scientific community to state that currently spending short or long periods outside her/his institution is a necessary condition for the relevant scientific development and the researcher's career progression - it can, nevertheless, favour its more permanent nature, especially if conditions at home are not the ones the individual is looking for, once he/she has completed graduation. As Constant and Massey demonstrate, since there is a negative correlation between age and staying abroad, the danger of permanent emigration is particularly strong in this group (CONSTANT; MASSEY, 2002), which makes it become relevant when we discuss the brain drain phenomenon. In fact, even the temporary migration of individuals searching for experiences and academic issues may become a "migration for life", resulting in a brain drain situation.

The hypotheses implied on the highly qualified migration are the Diaspora and the Exodus. This scenario leads us to the hypothesis of Diaspora vs Exodus concerning the emigration flow of highly qualified individuals, given that, in conditions of economic and social stability, the mobility of highly qualified individuals would rather typify the model of Diaspora, stressing the mutual benefits of intercultural exchanges opened by the circulation of academic, scientific and cultural cosmopolitan elites, whereas in conditions of both economic and social instability, the mobility of highly qualified individuals would typify the model of Exodus, stressing the idea that more skilled individuals are forced to the exile, allowing them to get a job and a remuneration corresponding to their education.

So, do people emigrate in the search for knowledge or in the search for an adequate job? In fact, there is yet no scientific evidence that may state one or the other of both hypotheses; we assume that both characterize the high-qualified emigration but some research proves that the Exodus is the most important reason for high skilled emigration in Southern countries (UNITED NATIONS, 2013, p. 2). In the meantime, research about Portugal demonstrates the same (GOMES, et al., 2015).

The recessive economic situation that Portugal is going through, being intervened by international financial institutions under a program of deep austerity, is, to a great extent, the explanation for a recent growth of Portuguese emigration taxes. Nevertheless, what seems to be novelty in the present emigration flow is the relevance that highly qualified individuals have in it, which, according to Breinbauer (2007), would mean not only the result of an exponential growth of 
tertiary education in Portugal in recent decades, but also the result of a labour market unable to absorb these qualifications. According to Baldwin (1970), this situation would identify the Portuguese brain drain phenomenon as a case of Brain Overflow, meaning that the academic system has had an over-production of high qualifications in a society whose work system is unable to absorb them, which forces highly qualified individuals to leave the country.

Additionally, and according to Ducatel et al. (2001), the Portuguese brain drain phenomenon could also result in a case of Brain Waste, i.e., skilled workers migrate into forms of employment not requiring the application of the skills and experience applied in the former job, or the skills attained with academic qualification.

Considering the fact that the authors did not find similar studies for Spain, Greece and Italy and, simultaneously, the fact that these other three countries had also experienced a recessive economic situation, being also stressed by international financial institutions under a program of deep austerity, we consider, to a great extent, that high qualified emigration from these countries to developed European countries is a consequence of that economic crisis, similarly to what happens in Portugal.

This outward movement from these countries is so strong that it would limit the use of educational investment in the sending countries, creating favourable conditions for their re-use by the more developed countries (BEINE; DOCQUIER; RAPOPORT, 2008) on a free-basis cost.

\section{Some numbers of the emigration from Portugal, Spain, Greece and Italy}

Portugal has always been a country of emigration, particularly on the last half of the $20^{\text {th }}$ century. However, over the last decades there has been a strong qualitative change in its emigrants, considering their academic qualifications.

Figures from Table 2 are clear about the increase of Portuguese highly skilled emigration, calling for a careful reflection on the subject. According to the data provided by the Observatory of Emigration (2014), between 2000/2001 and $2010 / 2011$, the number of emigrants with a higher education degree increased $88.0 \%$, reaching values close to $10.0 \%$ of the total Portuguese emigrants. In addition, Portuguese emigration has grown between 2000 and 2011, but this 
Table 2. Emigrant population in Portugal, over 15 years old, in OECD.

\begin{tabular}{lccccc}
\hline & \multicolumn{2}{c}{ Emigrant population } & \multicolumn{3}{c}{ Emigration rate } \\
\cline { 2 - 6 } Period & $\begin{array}{c}\text { Total } \\
\text { (thousands) }\end{array}$ & $\begin{array}{c}\text { Highly } \\
\text { qualified } \\
\text { (thousands) }\end{array}$ & $\begin{array}{c}\text { Highly } \\
\text { qualified } \\
\text { (\%) }\end{array}$ & $\begin{array}{c}\text { Total } \\
\text { emigration } \\
\text { rate (\%) }\end{array}$ & $\begin{array}{c}\text { Emigration } \\
\text { rate of highly } \\
\text { educated } \\
\text { population (\%) }\end{array}$ \\
\hline 200 & $1,260,8$ & 81 & 6.4 & 12.8 & 8.0 \\
$2005-2006$ & $1,382,1$ & 119 & 8.6 & 13.5 & 11.6 \\
$2010-2011$ & $1,492,0$ & 147 & 9.9 & 14.2 & 12.9 \\
\hline
\end{tabular}

OECD: Organisation for Economic Co-operation and Development.

Source: Barro \& Lee; DIOC 2000, DIOC 2005/06, DIOC 2010/11, available http://www.oecd.

org/els/mig/dio.htm (2010).

growth was more pronounced in the highly skilled population $(88.0 \%)$ than in the total emigration values $(24.0 \%)$.

That growing trend of highly skilled emigration is even clearer in its contours when comparing the relative growth of the total emigration and highly qualified emigration over the same period.

In fact, the Portuguese emigration has grown between 2000 and 2011, but this growth was more pronounced in the highly skilled population, revealing a real process of "brain drain" in the country, which has worsened in recent years, due to the deteriorating living conditions in the country, in consequence of the financial crisis and the austerity program imposed by the "TROIKA" (International Monetary Fund, European Central Bank, European Union) towards its recovery. Also according to the Observatory of Emigration and INE/PORDATA (2015), between 2011 and 2014, Portugal lost about half a million persons $(100,978$ in $2011 ; 121,418$ in 2012; 128,108 in 2013 and 134,624 in 2014) and, despite the academic qualification of those emigrants is unknown, the research already carried out (the research projects BRADRAMO [2012-2015] and REMIGR 2012-2015) points to the fact that over 40,000 highly skilled individuals have emigrated.

In a way, this situation may be common to other countries, as it may be observed in Table 3.

As can be seen in Table 3, there is highly skilled emigration in the four countries under analysis, although this phenomenon is stronger in Portugal. This comes as natural given that Portugal, traditionally a country of emigrants, is the one that 
Table 3. Emigrant population $15+$ in OECD in 2010/2011.

\begin{tabular}{|c|c|c|c|c|c|c|c|c|}
\hline \multirow[b]{2}{*}{ Variable } & \multicolumn{4}{|c|}{ Total Population } & \multicolumn{4}{|c|}{ Female Population } \\
\hline & $\begin{array}{l}\text { Emigrant } \\
\text { population } \\
\text { (thousands) }\end{array}$ & $\begin{array}{l}\text { Highly } \\
\text { educated } \\
\text { emigrant } \\
\text { (thousand) }\end{array}$ & $\begin{array}{l}\text { Emigrant } \\
\text { rate (\%) }\end{array}$ & $\begin{array}{l}\text { Emigrant } \\
\text { rate of } \\
\text { the highly } \\
\text { educated } \\
\text { (\%) }\end{array}$ & $\begin{array}{l}\text { Emigrant } \\
\text { population } \\
\text { (thousands) }\end{array}$ & $\begin{array}{l}\text { Highly } \\
\text { educated } \\
\text { emigrant } \\
\text { (thousand) }\end{array}$ & $\begin{array}{c}\text { Emigrant } \\
\text { rate (\%) }\end{array}$ & $\begin{array}{l}\text { Emigrant } \\
\text { rate of } \\
\text { the highly } \\
\text { educated } \\
\text { (\%) }\end{array}$ \\
\hline Portugal & 1,492 & 147 & 14.2 & 12.9 & 733 & 76 & 13.5 & 11.2 \\
\hline Spain & 738 & 212 & 1.9 & 2.3 & 401 & 112 & 2.0 & 2.3 \\
\hline Greece & 655 & 143 & 6.4 & 5.8 & 309 & 59 & 5.9 & 4.3 \\
\hline Italy & 2,309 & 401 & 4.4 & 7.9 & 1,076 & 173 & 4.0 & 6.5 \\
\hline
\end{tabular}

OECD: Organisation for Economic Co-operation and Development.

Source: DIOC http://www.oecd.org/els/mig/dio.htm (2011).

has, in fact, the highest emigration rate. Of the four countries under analysis, Portugal is the one that presents higher emigration rates, both in general terms and in terms of highly qualified labour force. In the Spanish case, emigration is negligible; moreover, it should be noted that the highly skilled emigration rate is higher than the general emigration rate. Also in Italy, the skilled emigration rate is greater than the emigration rate in general, with the former almost doubling the latter. The different rates that emigration, skilled and general, presents in the four countries clearly reveal that the phenomenon does not have equal importance in the four countries considered, being more worrying in Portugal and Greece. It is also interesting to notice the feminization of emigration from the four countries, particularly Portugal and Spain, both in the context of the total emigration and in highly skilled emigration.

Data on the number of emigrants from these southern European countries and their weight in the population cause some perplexity, especially given the level of unemployment recorded in each of these countries. In fact, as depicted in Table 4, since the 1990s and 2000s Spain and Greece have much higher unemployment rates than Portugal, whether in the low educated population or in the population with higher education qualifications, but, at the same time, these countries have a lower emigration level. However, as noted above, these are not the countries that show the highest emigration rates, but, rather, the Portuguese case.

Furthermore, this article highlights the amount spent by the country to graduate individuals in an emigration situation, in order to allow an understanding of the financial effort that the countries, as a whole (public and private effort), carry out, and from which they obtain no return (albeit there is a direct return to the 
Table 4. Unemployment rate by educational level (\%). ${ }^{2}$

\begin{tabular}{lcccccccc}
\hline \multirow{2}{*}{ Variable } & \multicolumn{2}{c}{ Total } & \multicolumn{2}{c}{ ISCED 2 } & \multicolumn{2}{c}{ ISCED 3-4 } & \multicolumn{2}{c}{ ISCED 5-8 } \\
\cline { 2 - 9 } & $\mathbf{1 9 9 2}$ & $\mathbf{2 0 1 4}$ & $\mathbf{1 9 9 2}$ & $\mathbf{2 0 1 4}$ & $\mathbf{1 9 9 2}$ & $\mathbf{2 0 1 4}$ & $\mathbf{1 9 9 2}$ & $\mathbf{2 0 1 4}$ \\
\hline Spain & 17.7 & 24.5 & 18.7 & 33.8 & 19.6 & 24.2 & 11.9 & 14.8 \\
Portugal & 4.0 & 14.1 & 4.4 & 15.3 & 4.3 & 15.3 & 1.1 & 10.0 \\
Greece & 7.9 & 26.5 & 6.1 & 28.2 & 12.5 & 30.2 & 5.5 & 20.0 \\
Italy & 9.3 & 12.7 & 9.2 & 16.6 & 10.7 & 11.9 & 5.2 & 7.9 \\
EU 28) & - & 10.2 & - & 18.5 & - & 9.4 & - & 6.1 \\
\hline
\end{tabular}

ISCED: International Standard Classification of Education.

Source: Produced by the authors from PORDATA (2016).

emigrants resulting from the financial situation that they come to attain in the country that receives those labour-skilled workers), considering the impact that such expenditure is likely to result in each country. To determine those amounts, data from Education at a Glance (OECD, 2014) have been used.

\section{To export skilled labour force on a free cost basis: the cases of Portugal, Spain, Greece and Italy}

As stated above, one of the research objectives is to do the "accounting" of skilled emigration. This calculation is more urgent given that educating a young person is not an inexpensive activity, either for taxpayers or for students/families, and that this investment is even heavier for the least developed countries in times of crisis such as the one that the country is undergoing.

To educate is an extraordinarily demanding task in financial terms (CABRITO, 2002; CERDEIRA, 2009; CERDEIRA et al., 2014), because of the specialised material resources and highly qualified human resources it requires, the forgone earnings and education living costs, with the aggravating circumstance that only in the medium/long term will the results arising there from be felt. In this "brain drain" situation, the countries that receive that labour force will become owners of a priceless raw material, "knowledge", on a free cost basis, while the exporting countries will impoverish in financial, professional and intellectual terms. Returning to a sentence from Maurice Dobb, in the

Note: UNESCO (United Nations Educational, Scientific and Cultural Organization) developed the ISCED to facilitate comparisons of education statistics and indicators across countries on the basis of uniform and internationally agreed definitions. So: ISCED 2 - Lower Secondary Education; ISCED 3-4: Secondary and Post-secondary no Tertiary Education; ISCED 5-8: Tertiary Education. See more at: http://www.uis.unesco.org/Education/Pages/international-standard-classification-of-education. aspx\#sthash.PP3U9wh5.dpuf. 
1970s, when he stated that the underdeveloped countries are the backyards of developed countries. This situation remains, almost fifty years later, in its essence; only the raw material that developed countries will earn from the others has changed: individuals and knowledge.

To determine the wealth attained by the countries receiving Portuguese, Spanish, Greek and Italian highly-qualified emigrants, we pursue closely the methodology followed by Altbach (2013), who, in his work The State of Higher Education 2013 (chapter 8, pp. 103-107), puts forward, through a few examples, how much the "brain exporting countries" "offer" to the recipient countries in a mobility that takes place from developing countries to developed countries. In his article, Altbach (2013) strikingly argues exactly with the very high amount that countries such as the United States receive, through the import of skilled labour force, at zero cost.

Following Altbach (2013), for this accounting, we had in mind:

- financial resources that the countries/taxpayers spend to educate their young, the "direct public costs";

- income taxes countries would raise on the income that would probably be earned by young people if they were working and not studying;

- students' opportunity costs, i.e., the salary students would earn if they were not studying;

- financial resources that students/families spend on their education, the "direct private costs";

To note that the calculus considered the fact that, to achieve a higher education degree, education expenses are made with the previous educational level, i.e., the secondary degree. Thus, then values shown correspond to the total expenditure incurred by countries and by the students and their families to achieve progressively the Baccalaureate and the diploma of higher education.

The values for each of the above mentioned indicators were taken from 2014 Education at a Glance: OECD Indicators, Indicator 7: What are the incentives to invest in education? and relate to 2010.

The analysis of the figures from the Table 5 allows some comments, such as: 
- In the four countries under analysis, it is more expensive to guarantee higher education studies to a young man than to a young woman, despite the fact that the amounts spent with each one are very close;

- Portugal is the cheapest country to conclude higher education studies; conversely, in Italy costs more than double the expenditures incurred in Portugal and more about $60 / 70.0 \%$ of costs in Spain and Greece;

- Spain and Greece spend almost the same amount for a young man/woman to attain a higher education degree;

- In Greece and Italy the private costs of higher education are higher than public costs (in fact, significantly higher), contrary to the situation that takes place in Spain and Portugal; this points to an uneven higher education funding policy in the four countries, with a lower participation of households in higher education funding, in the two Iberian countries.

Considering the total expenditure incurred in each country with the education of a young man/woman with higher education, it is important to compare those figures with the GDP per capita of each country; this indicator somehow measures the population's quality/standard of living. Given that the expenditure with education is provided by the official statistics by gender, it was decided to use the expenditure incurred with the education of a young man for this comparison. Note the Table 6.

Table 5. Public and private costs with a man/woman to hold higher education (when compared to a man/woman who has reached the lower level of education) and cumulative total, in 2010 (in USD ppps). ${ }^{3}$

\begin{tabular}{lcccc}
\hline Variable & & Public costs & Private costs & Total costs \\
\hline \multirow{2}{*}{ Portugal (2010) } & Woman & 41,166 & 37,060 & 78,226 \\
& Man & 41,340 & 38,318 & 79,658 \\
Spain (2010) & Woman & 53,274 & 46,984 & 100,258 \\
& Man & 53,360 & 47,921 & 101,281 \\
Greece (2009) & Woman & 37,619 & 63,525 & 101,144 \\
& Man & 37,712 & 76,229 & 113,941 \\
Italy (2008) & Woman & 74,005 & 94,721 & 168,726 \\
& Man & 75,887 & 102,765 & 178,652 \\
\hline
\end{tabular}

Source: Adapted from Education at a Glance: OECD Indicators, Table A7, 2014 (2016).

3 Note: Attached are the calculations of the amounts of public and private costs disaggregated for each country. The values presented refer to 2010, the last date with known official figures regarding the quotas of skilled emigrants for these countries. 
The above values clearly reveal how expensive it is to provide a young man higher education qualifications. As it would be expected, Italy and Greece have the most significant relationship between the total costs of training a higher education student and the country's GDP per capita.

Continuing to follow Altbach (2013), it has been calculated, albeit somewhat roughly, how much the countries where Portuguese, Spanish, Italian and Greece highly skilled emigrants go to are funded by taxpayers. This calculus has been made according to the number of highly skilled emigrants of each country, per gender in 2010 and the total public and private cost each country has with a man/woman to hold higher education.

Data from Table 7 are very explicit about the level of wealth spent by the countries under analysis in the education of the their highly qualified professionals, which they export to OECD (Organisation for Economic Co-operation and Development) developed countries, and that, in 2010, exceeded 8,8 billion euros for Portugal, 16,3 billion euros for Spain, 11,8 billion euros for Greece and 53,3 billion euros for Italy. In consequence, around 90,5 billion euros is the estimated total amount that these four countries will lose if all the highly qualified emigrants remain as emigrants throughout their whole working life. Simultaneously, those 90,5 billion euros is the amount the receiving countries get on a free-basis cost.

Finally, the weight of total costs on education in the GDP of the countries analysed is presented in Table 8 .

Table 6. Relationship between the total expenditure for the education of a young man with higher education and GDP per capita, in US\$, in 2010. ${ }^{4}$

\begin{tabular}{lcccc}
\hline Variable & GDP pc $€$ (1) & GDP pc \$ (2) & $\begin{array}{c}\text { Total costs for a man } \\
\text { attaining higher } \\
\text { education \$ (3) }\end{array}$ & $\begin{array}{c}\text { Total costs versus } \\
\text { GDP pc \$ (3/2) }\end{array}$ \\
\hline Portugal & 17,000 & 22,309 & 79,658 & 3,6 \\
Spain & 23,200 & 30,445 & 101,281 & 3,3 \\
Greece & 20,300 & 26,640 & 113,941 & 4,3 \\
Italy & 26,800 & 35,170 & 178,652 & 5,1 \\
\hline
\end{tabular}

Source: GDP pc, EUROSTAT, National Accounts, in htpp://ac.europa.eu/eurostat, accessed on February 26, 2016 (2016).

\footnotetext{
${ }^{4}$ Note: It has been used the medium exchange rate on the week 20 to 26 December 2010, from OANDA, www.OANDA.com: $1 €=1,3123$ USA\$.
} 
Table 7. Total estimated costs (public + private) of the education of emigrants holding HE qualifications, residents in OECD countries, in 2010 (USD ppp) - Portugal, Spain, Greece, Italy.

\begin{tabular}{|c|c|c|c|c|c|c|}
\hline & & Man & Female & Man & Female & Total \\
\hline Variable & $\begin{array}{l}\text { educated } \\
\text { emigrant } \\
\text { (thousand) }\end{array}$ & $\begin{array}{c}\text { Highly } \\
\text { educated } \\
\text { emigrant } \\
\text { (thousand) }\end{array}$ & $\begin{array}{l}\text { Highly } \\
\text { educated } \\
\text { emigrant } \\
\text { (thousand) }\end{array}$ & Total Costs & Total Costs & Total Costs \\
\hline Portugal & 147 & 71 & 76 & $5,655,718,000$ & $5,945,176,000$ & $11,600,894,000$ \\
\hline Spain & 212 & 100 & 112 & $10,128,100,000$ & $11,228,896,000$ & $21,356,996,000$ \\
\hline Greece & 143 & 84 & 59 & $9,571,044,000$ & $5,967,496,000$ & $15,538,540,000$ \\
\hline Italy & 401 & 228 & 173 & $40,732,656,000$ & $29,189,598,000$ & $69,922,254,000$ \\
\hline
\end{tabular}

HE: higher education; OECD: Organisation for Economic Co-operation and Development. Source: Authors' production, based on OECD data (2016).

Table 8. Weight of total costs on education of highly qualified emigrants in the GDP.

\begin{tabular}{lccc}
\hline Variable & $\begin{array}{c}\text { GDP - ESA10 } \\
\text { (billion } \boldsymbol{\epsilon})\end{array}$ & Total costs (billion $\boldsymbol{€})$ & Total costs/PIBx100 \\
\hline Portugal & 179,9 & 8,8 & 4,9 \\
Spain & $1,080,9$ & 16,3 & 1,5 \\
Greece & 226 & 11,8 & 5,2 \\
Italy & $1,605,7$ & 53,3 & 3,3 \\
\hline
\end{tabular}

ESA10 - European System of Accounts 2010.

Source: PIB, EUROSTAT, National Accounts, in htpp//: ac.europa.eu/eurostat, accessed on February 26, 2016.

The above figures clearly illustrate the weight of costs that countries have made in the education of their highly skilled emigrants, being the most significant cases Greece and Portugal.

Regardless of the difference, which stressed the social and economic context of each country, it may be stated that the host countries of these skilled-labour will benefit completely from those amounts, once they have paid nothing for the education of these highly qualified emigrants.

\section{Final thoughts}

The research carried out gives a clear picture of the investment that Portugal, Spain, Greece and Italy have made to qualify their highly skilled emigrants. In spite of the differences that may be found in the amounts spent by each country 
to qualify each student with a higher education degree and to qualify all these emigrants, results allow concluding that these four South European countries lose an important part of their wealth, qualifying people whose gains will be appropriated by Northern European developed countries.

In consequence, the previous exercise aimed to determine how much Portugal, Spain, Greece and Italy have spent in the education of the highly qualified professionals who left the country, materialising a havoc of qualifications never before experienced. This calculation would simultaneously determine the wealth that the countries receiving this labour force take possession of, without having contributed with any amount to its education.

Accordingly, on the basis of the indicators from A7 OECD (2014) and following the methodology used by Altbach (2013) for this type of calculation, it was determined the value that these countries (through the State budget and through the students/families) have spent with the education of that labour force.

In 2010, with its skilled emigrants, Portugal, Spain, Greece and Italy "offered" to the host countries over 90 billion euros. We conclude with Altbach: "What can be done? The rich countries can, in the spirit of the Millennium Development Goals, remit to the developing countries that are major exporters of talent, the costs incurred by those countries for educating their non-returning young academics..." (2013, p. 106). 


\section{Transferência de investimento na educação com base no custo livre: alguns dados de Portugal, Espanha, Grécia e Itália}

\section{Resumo}

Durante décadas, a educação tem sido perspectivada como um instrumento de mobilidade social e, também, como uma ferramenta ao serviço do crescimento econômico e do desenvolvimento social. Ao longo dos últimos anos tem vindo a assistir-se a um movimento de diplomados altamente qualificados dos países periféricos do sul da Europa para os países mais desenvolvidos da UE e da OCDE. Neste artigo, analisamos a realidade de quatro países: Portugal, Espanha, Grécia e Itália. A fim de analisar o impacto socioeconómico desta fuga de cérebros, será introduzida uma estimativa utilizando as estatísticas da OCDE (2014) relativas aos custos públicos e privados para educar um aluno desde a escola primária até a conclusão do Ensino Superior. Apesar das diferenças entre as experiências destes países, não há dúvida de que estes países têm vindo a "oferecer" trabalhadores altamente qualificados gratuitamente ou numa base de custo zero aos paises "importadores".

Palavras-chave: Despesas públicas e privadas de educação. Ensino superior. Emigração altamente qualificada.

\section{Transferencia de inversión en la educación basada en el precio libre: algunos datos de Portugal, España, Grecia e Italia}

\section{Resumen}

Durante décadas, la educación ha sido considerada una herramienta para la movilidad social y, también, una herramienta para el crecimiento económico y el desarrollo social. En los últimos años, estamos asistiendo a un movimiento de titulados altamente cualificados de los países de la periferia del sur de Europa a los países más desarrollados de la UE y de la OCDE. En este artículo, analizamos la realidad de cuatro países: Portugal, España, Grecia e Italia. Con el fin de analizar el impacto socioeconómico de la fuga de cerebros, una estimación se introducirá utilizando estadísticas de la OCDE (2014) de los gastos públicos y privados para educar a un estudiante de la escuela primaria hasta que complete el nivel terciario. A pesar de las diferencias entre las experiencias de estos países, no hay duda de que estos países están "ofreciendo" trabajadores altamente cualificados de forma gratuita o en un coste de cero a los países "importadores".

Palabras clave: Gastos públicos y privados en educación. Educación superior. Emigración altamente calificada. 


\section{References}

ALTBACH, P. G. The world is not flat: the brain drain and higher education in the 21st century. In: GLASS, A. (Ed.). The state of higher education 2013. Paris: OECD Higher Education Programme (IMHE), 2013. p. 103-7.

BALDWIN, G. B. Brain drain or overflow. Foreign Affairs, n. 48, n. 2, p. 358-72, jan. 1970.

BARKHOLT, $\mathrm{K}$. The Bologna process and integration theory: convergence and autonomy. Higher Education in Europe, v. 30, n. 1, p. 23-9, Apr. 2005. doi:10.1080/03797720500087980

BARRO, R. J.; LEE, J.-W. A new data set of educational attainment in the world, 1950-2010. 2010. Available from: <http://www.barrolee.com/papers/ Barro_Lee_Human_Capital_Update_2012Oct.pdf $>$. Acess: 2016 Apr. 1.

BEINE, M.; DOCQUIER, F.; RAPOPORT, H. Brain drain and human capital formation in developing countries: winners and losers. The Economic Journal, v. 118, n. 528, p. 631-652, Apr. 2008. doi:10.1111/j.1468-0297.2008.02135.x

BRADRAMO. Êxodo de competências e mobilidade académica de Portugal para a Europa. 2015. Available from: <http://www.bradramo.pt/>. Acess: 2015 Dec 20.

BREINBAUER, A. Brain drain - Brain circulation or... What else happens or should happen to the brains some aspects of qualified person mobility/ migration. St. Louis: Ideias; 2007. Available from: <http://ideas.repec.org/p/ wsr/wpaper/y2007i004.html>. Access: 2013 Nov 12.

CABRITO, B. O financiamento do ensino superior: condição social e despesas de educação dos estudantes universitários em Portugal. Lisboa: Educa, 2002.

CASTLES, S.; MILLER, M. J. The age of migration: international population movements in the modern world. 3. ed. Basingstoke: Palgrave Macmillan, 2003.

CERDEIRA, L. O financiamento do ensino superior português: a partilha de custos. Lisboa: Almedina, 2009.

CERDEIRA, L. et al. Custos de educação dos estudantes do ensino superior. Lisboa: Educa, 2014.

CHARLE, C. et al. Ensino superior: o momento crítico. Educação e Sociedade, v. 25 , n. 88 , p. $960-75$, out. 2004. doi: 10.1590/S0101-73302004000300015 
CONSTANT, A.; MASSEY, D. S. Return migration by German guest workers: neoclassical versus new economic theories. International Migration, v. 40, n. 4, p. 5-38, 2002.

DOCQUIER, F.; MARFOUK, A. Brain drain in developing countries. World Bank Economic Review, v. 2, n. 2, p. 193-218, Jun 2007. doi:10.1093/wber/lhm008

DUCATEL, K. et al. The mobility of academic researchers: academic careers \& recruitment in ICT and biotechnology. Brussels: European Commission, 2001.

DUCLERT, V.; CHARIOT, A. Quel avenir pour la recherche? Paris: Flammarion, 2003.

EUROPEAN COMMISSION. Erasmus: facts, figures \& trends: the European Union support for student and staff exchanges and university cooperation in 20132014. Brussels: European Commission, 2015. Available from: $<$ http://ec.europa.eu/ education/library/statistics/erasmus-plus-facts-figures_en.pdf $>$. Acess: 2016 Mar. 23.

EUROSTAT. National accounts. Brussels: European Commission, 2016. Available from: htpp://ac.europa.eu/Eurostat. Access: 2016 Feb. 26.

GOMES, R. M. et al. Fuga de cérebros: retratos da emigração qualificada portuguesa. Lisboa: Bertrand, 2015.

HAMILTON, K. Migration and development: blind fact and hand-to-find facts. Washington: Migration Policy Institute, 2003.

HEUER, N. The effect of occupation-specific brain drain on human capital. Tubingen: University of Tubingen, 2011. (Working papers in economic and finance, 7).

HORTALE, V. A.; MORA, J.-G. Tendências das reformas da educação superior na Europa no contexto do processo de Bolonha. Educação e Sociedade, v. 25, n. 88, p. 937-60, 2004. doi:10.1590/S0101-73302004000300014

LIEBIG, T. Immigration as a supply-side problem: the international competition for highly-skilled migrants. 2004. 151 p. (PhD dissertation) - Universität St. Gallen, St. Gallen, 2004.

LODIGIANI, E.; MARCHIORI, L. M., SHEN, I.-1. et al. Revisiting the brain drain literature with insights from a general equilibrium world model, 2013. Available from: $<$ http://www.ferdi.fr/sites/www.ferdi.fr/files/lodigiani.pdf > . Access: 2014 Apr. 23.

OBSERVATORY OF EMIGRATION. Portuguese emigration factbook, Lisboa, 2014. Available from: <http://www.observatorioemigracao. secomunidades.pt/np4/home.html>. Acess: 2014 Dec. 14 


\section{OECD - ORGANIZATION FOR ECONOMIC CO-OPERATION AND}

DEVELOPMENT. Database on immigrants in OECD and non-OECD countries: DIOC. Paris: OECD Publishing, 2015. Available at: http://www.oecd.org/els/mig/ databaseonimmigrantsinoecdcountriesdioc.htm. Access: 8 Oct. 2015.

Publishing, 2014.

Education at a glance 2014: OECD indicators. Paris: OECD

PORDATA - Base de Dados Portugal Contemporâneo. Emprego e mercado de trabalho: população desempregada. Lisboa, 2015. Available from: $<$ http:// www.pordata.pt/Home>. Access: 2016 Jun 4.

REMIGR. Regresso ao futuro: a nova emigração e a relação com a sociedade portuguesa. Lisboa: Universidade de Lisboa, 2015. Available from: $<$ http:// www.remigr.pt/>. Acess: 2015 Jun. 4.

SCHULTZ, T. Investment in human capital. American Economic Review, v. 51, p. $1-17,1961$.

UNITED NATIONS, Department of Economic and Social Affairs; OECD. World migration in figures: a joint contribution by N-DESA and the OECD to the United Nations High-Level Dialogue on Mingrantion and Development. OECD-UNDESA. Paris: OECD Publishing, 2013

ZAHARIA, S.; GIBERT, E. The entrepreneurial university in the knowledge society. Higher Education in Europe, v. 30, n. 1, p. 31-40, Apr. 2005. doi:10.1080/03797720500088038

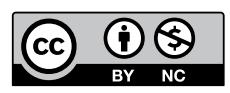

\section{Informações dos autores}

Luísa Cerdeira: PhD at the University of Lisbon - UL. Lisbon, Portugal. Contato: luisa. cerdeira@ie.ulisboa.pt

Belmiro Cabrito: PhD at the University of Lisbon - UL. Lisbon, Portugal. Contato: b.cabrito@ie.ulisboa.pt

Maria Lourdes Machado-Taylor: $\mathrm{PhD}$ at the Centre for Research in Higher Education Policies - CIPES. Matosinhos, Portugal. Contato: 1machado@cipes.up.pt

Tomás Patrocínio: PhD at the University of Lisbon - UL. Lisbon, Portugal. Contato: patrocinio.tomas@gmail.com 